\title{
Application of Linear Programming in Budgeting Costs for the Compensation of Employees
}

\author{
Sungatullina L.B. \\ Kazan Federal University, Institute of Management, Economics and Finance, Kazan, 420008, Russia \\ Emai: Lilia_sungat@mail.ru
}

\section{Doi:10.5901/mjss.2014.v5n24p388}

\begin{abstract}
The article contains a theoretical and methodological aspects of budgeting expenditures on compensation of employees based on the determination of optimal values of the limited financial resources of the company. We propose a logical organization of budgeting the expenditures using linear programming. Recommended are calculations and measures to control the cost of remuneration in accordance with the objectives of the company.
\end{abstract}

Keywords: expenditures on employee compensation, budgeting, linear programming, labor productivity.

\section{Introduction}

Budgeting system is of special importance to generate information which is necessary to prioritize company's current activities and to provide a basis for assessing opportunities to improve compensation expenses. It allows to generate information about distribution and consumption of resources allocated for employee pay and stimulating payments to employees. In order to harmonize current and future challenges and the results achieved in effective use of financial resources for personnel compensation in the budget cost management it is advisable to use linear programming which contributes to optimization of expenditure level for compensations for short term and the creation of a system of coordinates for both the business as a whole, and for expenditure on compensations.

\section{Method}

The economic essence of linear programming is to study the operations associated with the determination of optimal values of the objective function of linear variables coupled with the use of limited resources. At the same time mathematical logics of factors interchangeability should always be combined with logically sound understanding of the nature of the phenomenon studied.

Within budget costs management of compensations linear programming is effective to solve the problems of funds rational use for employee pays and incentive payments. In particular, when budgeting systematic incentive payments, it is advisable to correct these expenses as a result of changes in the correlation of average increase in the employee pay for every one percent increase in worker's productivity. For this reason, to determine the maximum coefficients for computing systematic incentive payments it is possible to use the method of the generalized problems from of linear programming.

\section{Results}

We investigate the possibility to apply the approach proposed to cost budgeting of employees pay on the example of JSC "Shoe Factory" Spartak, one of the oldest shoe companies in Russia. This company uses two sets of coefficients for computing systematic incentive payments:

1) for accomplishment of a plan in the range from 0 to 1,0;

2) for the turnover of the designs (for the substantive and support staff) and for non-standard work day (for managerial staff, engineers and technical workers) in the range from 0 to 0,3 .

When budgeting costs of compensations it is necessary to determine the values of the above coefficients that can be corrected to comply with the correlation between employee pay increase and one per cent increase of worker's productivity. To do this, we are given two numeric vectors with eleven coordinates each. Coordinates of the first mean change rate in the average value of the employee pay, the coordinates of the second mean rate of change in labor 
productivity. The coordinates are changed sequentially from 1,0 to 2,0 in increments of 0,1 . At the same time, we presume that the value of the basic compensation per worker, and the value of worker's productivity in the planning period may remain at the same level (the coefficient is 1,0 ), or to increase at least twice (the coefficient is 2,0). With these vectors $\mathrm{M}_{1}$ matrix is constructed (Table 1).

Table 1. Matrix of correlation between change rates of the average value of the employee pay and labor productivity $\left(\mathrm{M}_{1}\right)$

\begin{tabular}{|c|c|c|c|c|c|c|c|c|c|c|c|c|}
\hline \multirow{2}{*}{\multicolumn{2}{|c|}{ Value }} & \multicolumn{11}{|c|}{ Change coefficients of average value of employee pay } \\
\hline & & 1,0 & 1,1 & 1,2 & 1,3 & 1,4 & 1,5 & 1,6 & 1,7 & 1,8 & 1,9 & 2,0 \\
\hline 흐 & 1,0 & 1,00 & 1,10 & 1,20 & 1,30 & 1,40 & 1,50 & 1,60 & 1,70 & 1,80 & 1,90 & 2,00 \\
\hline 으 & 1,1 & 0,91 & 1,00 & 1,09 & 1,18 & 1,27 & 1,36 & 1,45 & 1,55 & 1,64 & 1,73 & 1,82 \\
\hline$\frac{\infty}{\bar{d}}$ & 1,2 & 0,83 & 0,92 & 1,00 & 1,08 & 1,17 & 1,25 & 1,33 & 1,42 & 1,50 & 1,58 & 1,67 \\
\hline & 1,3 & 0,77 & 0,85 & 0,92 & 1,00 & 1,08 & 1,15 & 1,23 & 1,31 & 1,38 & 1,46 & 1,54 \\
\hline${ }^{s}: \geq$ & 1,4 & 0,71 & 0,79 & 0,86 & 0,93 & 1,00 & 1,07 & 1,14 & 1,21 & 1,29 & 1,36 & 1,43 \\
\hline 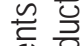 & 1,5 & 0,67 & 0,73 & 0,80 & 0,87 & 0,93 & 1,00 & 1,07 & 1,13 & 1,20 & 1,27 & 1,33 \\
\hline$\frac{\mathscr{D}}{\mathrm{N}}$ 임 & 1,6 & 0,63 & 0,69 & 0,75 & 0,81 & 0,88 & 0,94 & 1,00 & 1,06 & 1,13 & 1,19 & 1,25 \\
\hline षे & 1,7 & 0,59 & 0,65 & 0,71 & 0,76 & 0,82 & 0,88 & 0,94 & 1,00 & 1,06 & 1,12 & 1,18 \\
\hline$\stackrel{0}{0}$ & 1,8 & 0,56 & 0,61 & 0,67 & 0,72 & 0,78 & 0,83 & 0,89 & 0,94 & 1,00 & 1,06 & 1,11 \\
\hline స్ర & 1,9 & 0,53 & 0,58 & 0,63 & 0,68 & 0,74 & 0,79 & 0,84 & 0,89 & 0,95 & 1,00 & 1,05 \\
\hline $\bar{u}$ & 2,0 & 0,50 & 0,55 & 0,60 & 0,65 & 0,70 & 0,75 & 0,80 & 0,85 & 0,90 & 0,95 & 1,00 \\
\hline
\end{tabular}

Coordinates of the first vector recorded in the first line $M_{1}$, and of the second - in the first column. Elements $\left(m_{i j}\right)$ of $M_{1}$ matrix are completed by the following rule: $m_{i j}=m_{0 j} / m_{i o}(i, j \geq 1)$. Elements of the main diagonal are equal to one, those that are located above the main diagonal are more than 1,0 and those lower will be less than 1.0. For further reasoning, elements less than or equal to one are suitable, as it is only with this correlation that rate of change in worker productivity will equal or exceed the rate of change of the average employee pay. Therefore, the $M_{1}$ matrix is transformed to a $M_{2}$ matrix (Table 2).

Elements of $\mathrm{M}_{2}$ matrix are used to calculate the planned expenditure on staff remuneration, including expenses for systematic incentive payments taking into account corrected coefficients. To do this, the general formula for calculating the expenditures for employees' compensation is applied:

$\mathrm{EC}_{\text {worker }}=\mathrm{EC}_{\text {employee.pay. }}+\mathrm{IP}+\mathrm{EC}_{\text {syst.incentive.pay }}(1)$

where: $\mathrm{EC}$ employee.pay - the expenses for employee pay, MU.;

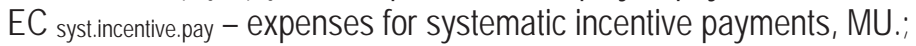

IP - insurance premiums accrued on payments to employees, according to the legislation, MU.

Table 2. The transformed matrix of correlation between change rates of the average employee pay and labor productivity $\left(\mathrm{M}_{2}\right)$.

\begin{tabular}{|c|c|c|c|c|c|c|c|c|c|c|c|c|}
\hline \multirow{2}{*}{\multicolumn{2}{|c|}{ Values }} & \multicolumn{11}{|c|}{ Change coefficients of average employee pay } \\
\hline & & 1,0 & 1,1 & 1,2 & 1,3 & 1,4 & 1,5 & 1,6 & 1,7 & 1,8 & 1,9 & 2,0 \\
\hline \multirow{11}{*}{ 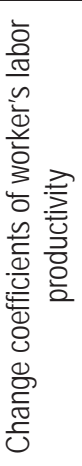 } & 1,0 & 1,00 & 1,00 & 1,00 & 1,00 & 1,00 & 1,00 & 1,00 & 1,00 & 1,00 & 1,00 & 1,00 \\
\hline & 1,1 & 0,91 & 1,00 & 1,00 & 1,00 & 1,00 & 1,00 & 1,00 & 1,00 & 1,00 & 1,00 & 1,00 \\
\hline & 1,2 & 0,83 & 0,92 & 1,00 & 1,00 & 1,00 & 1,00 & 1,00 & 1,00 & 1,00 & 1,00 & 1,00 \\
\hline & 1,3 & 0,77 & 0,85 & 0,92 & 1,00 & 1,00 & 1,00 & 1,00 & 1,00 & 1,00 & 1,00 & 1,00 \\
\hline & 1,4 & 0,71 & 0,79 & 0,86 & 0,93 & 1,00 & 1,00 & 1,00 & 1,00 & 1,00 & 1,00 & 1,00 \\
\hline & 1,5 & 0,67 & 0,73 & 0,80 & 0,87 & 0,93 & 1,00 & 1,00 & 1,00 & 1,00 & 1,00 & 1,00 \\
\hline & 1,6 & 0,63 & 0,69 & 0,75 & 0,81 & 0,88 & 0,94 & 1,00 & 1,00 & 1,00 & 1,00 & 1,00 \\
\hline & 1,7 & 0,59 & 0,65 & 0,71 & 0,76 & 0,82 & 0,88 & 0,94 & 1,00 & 1,00 & 1,00 & 1,00 \\
\hline & 1,8 & 0,56 & 0,61 & 0,67 & 0,72 & 0,78 & 0,83 & 0,89 & 0,94 & 1,00 & 1,00 & 1,00 \\
\hline & 1,9 & 0,53 & 0,58 & 0,63 & 0,68 & 0,74 & 0,79 & 0,84 & 0,89 & 0,95 & 1,00 & 1,00 \\
\hline & 2,0 & 0,50 & 0,55 & 0,60 & 0,65 & 0,70 & 0,75 & 0,80 & 0,85 & 0,90 & 0,95 & 1,00 \\
\hline
\end{tabular}


According to formula 1 the expenses of employee pay are known; insurance premiums can be neglected as their influence is insignificant; and the last addend is calculated as a linear combination of expenses for employee pay per each worker and correctable coefficients of computing systematic incentive payments that have to be defined. It is possible to simplify the task, as the expenses for employee pay are of the same amount for a particular grade. In general, these correctable coefficients are two $n$-dimensional vectors ( $n$ - number of grades of remuneration). For each grade one should calculate some correctable coefficients that form an element set of the $n$-dimensional vector:

$$
\begin{aligned}
& K_{x}=\left(K_{x 1}, \cdots, K_{x n}\right)(2) \\
& K_{y}=\left(K_{y 1}, \cdots, K_{y n}\right)(3)
\end{aligned}
$$

where: $K_{x}$ is the first set of correctable coefficients of computing systematic incentive payments;

$\mathrm{K}_{\mathrm{y}}$ is a second set of correctable coefficients of computing systematic incentive payments.

It is known that all the elements of the $K_{x}$ vector are in the interval of $0 \leq K_{x i} \leq 1$, and the elements of the $K_{y}$ vector are in the interval $0 \leq K_{y i} \leq 0,3$, where $i$ is the number of coordinates of the $n$-dimensional vector $; i=1, \cdots, n$. These correctable coefficients may reach zero only when:

$\mathrm{A}=\mathrm{EC}_{\text {worker }}-\mathrm{EC}_{\text {employee.pay }}=0$ (4)

where: $A$ is the expenses for systematic incentive payments ( a variable (a functional));

$\mathrm{EC}_{\text {worker }}, \mathrm{EC}_{\text {employee.pay }}$ have the same meaning as in formula 1.

To determine the minimum or maximum functional with additional inequality constraints on the unknown variables, we used a method to summarize the objectives from linear programming. To this end, we solve the system whose results allow to define a fixed set of correctable coefficients of computing systematic incentive payments - $K_{\mathrm{x}_{\mathrm{i}}}, \mathrm{K}_{\mathrm{y}_{\mathrm{i}}}$ :

$\mathrm{L}\left(\mathrm{K}_{\mathrm{x}}, \mathrm{K}_{\mathrm{y}}\right)=\left(\mathrm{K}_{\mathrm{x}_{1}}+\mathrm{K}_{\mathrm{y}_{1}}\right) \mathrm{a}_{1}+\left(\mathrm{K}_{\mathrm{x}_{2}}+\mathrm{K}_{\mathrm{y}_{2}}\right) \mathrm{a}_{2}+\cdots+\left(\mathrm{K}_{\mathrm{x}_{\mathrm{n}}}+\mathrm{K}_{\mathrm{y}_{\mathrm{n}}}\right) \mathrm{a}_{\mathrm{n}}-\mathrm{A}=0$ (5)

$0 \leq \mathrm{K}_{\mathrm{x}_{\mathrm{i}}} \leq 1,0 \leq \mathrm{K}_{\mathrm{yi}_{\mathrm{i}}} \leq 0,3, \mathrm{i}=1, \cdots, \mathrm{n}$

where: $L\left(K \_x, K \_y\right)$ - the difference between a linear combination of the expenses for employee pay by grades and of correctable coefficients for computing systematic incentive payments, and A functional.

$a_{n}-$ planned expenditure on employee pay of the $n$-th grade.

As a result, hyperplane in $2 n$ dimensions space and the hypercube (a convex set) are formed in the same space. If these sets disjoint, it is necessary to find at least one point of intersection. As this point we understand some fixed set of correctable coefficients for computing systematic incentive payments $-\mathrm{K}_{\mathrm{x}_{\mathrm{i}}}, \mathrm{K}_{\mathrm{y}_{\mathrm{i}}}$.

We consider two cases for searching the unknown coefficients. The first case is a special case, when the number of grades is equal to one, i.e. $n=1$. In this variant, there are two independent variables, therefore, it is the Cartesian coordinate system in a plane. Area of finding a solution is a rectangle with parallel sides to the axes OX and OY, with the two sides lying on these axes. Hyperplane in this case is a right line posed by the equation:

$\mathrm{L}\left(\mathrm{K}_{\mathrm{x}_{1}}, \mathrm{~K}_{\mathrm{y}_{1}}\right)=\mathrm{K}_{\mathrm{x}_{1}} \mathrm{a}_{1}+\mathrm{K}_{\mathrm{y}_{1}} \mathrm{a}_{1}-\mathrm{A}=0$ (6)

where $A$ has the same meaning as in formula 4;

$\mathrm{L}\left(\mathrm{K}_{\mathrm{x}_{1}}, \mathrm{~K}_{\mathrm{y}_{1}}\right), \mathrm{a}_{1}$ have the same meaning as in formula 5 with a single grade.

Results of value calculation of expression on the left side of formula 5 in the vertex of the rectangle with coordinates $B(0,0), C(1,0), D(0,0.3), E(1,0.3)$ can provide several options:

1) value $L(B), \cdots, L(E)$ have the same sign;

2) there is at least one value of $L$ that is equal to zero;

3) at least two values of $L$ have opposite signs.

With the first variant the situation has no solution. With the second variant the attack is the vertex of the rectangle whose substitution of $L$ gives zero. In the third variant, the equation of the right line should be drawn through the vertices of the rectangle with opposite $L$ values and find the point of intersection of expression 5 with the right line found which will be the desired solution, since if the line intersected with a rectangle, any point lying on the line within the rectangle is a solution. In this case, the fact that the area is convex is used.

When considering the general case of the search for the desired coefficients one should use the algorithm of the precedent discussed above. First, it is necessary to calculate the values of $L\left(\mathrm{~K}_{\mathrm{x}}, \mathrm{K}_{\mathrm{y}}\right)$ at the vertices of the hypercube. To do this, it is necessary to substitute coordinates of all possible sets of coefficients that can be formed from the values of $0,1.0 ; 0,0.3$. The first two values are used only for $\mathrm{K}_{\mathrm{x}}$, and the second two - only for $\mathrm{K}_{\mathrm{y}}$. Next, one must check which of the previous variants takes place. The conclusions are the same as the first special case, so further calculations are carried out for the third variant, when at the points with $\left(\mathrm{Kx}_{1}^{\prime}, \cdots, \mathrm{Kx}_{\mathrm{n}}^{\prime} ; \mathrm{Ky}_{1}^{\prime}, \cdots \mathrm{Ky}_{\mathrm{n}}^{\prime}\right),\left(\mathrm{Kx}_{1}^{\prime \prime}, \cdots, \mathrm{Kx}_{\mathrm{n}}^{\prime \prime} ; \mathrm{Ky}_{1}^{\prime \prime}, \cdots \mathrm{Ky}_{\mathrm{n}}^{\prime \prime}\right)$ variable $L$ has different signs. Accordingly, the equation of the right line is drawn in the $2 n$-dimensional space: 
$\frac{\mathrm{Kx}_{1}-\mathrm{Kx}_{1}^{\prime}}{\mathrm{Kx}_{1}^{\prime \prime}-\mathrm{Kx}_{1}^{\prime}}=\frac{\mathrm{Kx}_{2-} \mathrm{Kx}_{2}^{\prime}}{\mathrm{Kx}_{2}^{\prime \prime}-\mathrm{Kx}_{2}^{\prime}}=\cdots=\frac{\mathrm{Kx}_{\mathrm{n}} \mathrm{Kx}_{\mathrm{n}}^{\prime}}{\mathrm{Kx}_{\mathrm{n}}^{\prime \prime}-\mathrm{Kx}_{\mathrm{n}}^{\prime}}=\frac{\mathrm{Ky}_{1-} \mathrm{Ky}_{1}^{\prime}}{\mathrm{Ky}_{1}^{\prime \prime}-\mathrm{Ky}_{1}^{\prime}}=\frac{\mathrm{Ky}_{2}-\mathrm{Ky}_{2}^{\prime}}{\mathrm{Ky}_{2}^{\prime \prime}-\mathrm{Ky}_{2}^{\prime}}=\cdots=\frac{\mathrm{Ky}_{\mathrm{n}}-\mathrm{Ky}_{\mathrm{n}}^{\prime}}{\mathrm{Ky}_{\mathrm{n}}^{\prime \prime}-\mathrm{Ky}_{\mathrm{n}}^{\prime}}(7)$

To solve the system of equations 5 and equation 7, the last expression is converted to a parametric form:

$\mathrm{Kx}_{1}=\mathrm{Kx}_{1}^{\prime}+\mathrm{t}\left(\mathrm{Kx}_{1}^{\prime \prime}-\mathrm{Kx}_{1}^{\prime}\right)$,

...

$\mathrm{Kx}_{\mathrm{n}}=\mathrm{Kx}_{\mathrm{n}}^{\prime}+\mathrm{t}\left(\mathrm{Kx}_{\mathrm{n}}^{\prime \prime}-\mathrm{Kx}_{\mathrm{n}}^{\prime}\right)$

$\mathrm{Ky}_{1}=\mathrm{Ky}_{1}^{\prime}+\mathrm{t}\left(\mathrm{Ky}_{1}^{\prime \prime}-\mathrm{Ky}_{1}^{\prime}\right)$, (8)

$\cdots$

$\mathrm{Ky}_{\mathrm{n}}=\mathrm{Ky}_{\mathrm{n}}^{\prime}+\mathrm{t}\left(\mathrm{Ky}_{\mathrm{n}}^{\prime \prime}-\mathrm{Ky}_{\mathrm{n}}^{\prime}\right)$.

where $: \mathrm{Kx}_{1}^{\prime}, \cdots, \mathrm{Kx}_{\mathrm{n}}^{\prime} ; \mathrm{Ky}_{1}^{\prime}, \cdots \mathrm{Ky}_{\mathrm{n}}^{\prime} ; \mathrm{Kx}_{1}^{\prime \prime}, \cdots, \mathrm{Kx}_{\mathrm{n}}^{\prime \prime} ; \mathrm{Ky}_{1}^{\prime \prime}, \cdots \mathrm{Ky}_{\mathrm{n}}^{\prime \prime}$ - the coordinates of the one and the other of the points of correctable coefficients for computing of systematic incentive payments in which the values of $L$ variable are opposite;

$\mathrm{t}$ - parameter of the right line recorded in formula 7.

To find the t value, expression 8 is substituted into formula 5 and the desired quantity is calculated:

$\mathrm{t}=\frac{\mathrm{A}-\left(\mathrm{Kx}_{1}^{\prime}+\mathrm{Ky}_{1}^{\prime}\right) \mathrm{a}_{1}-\left(\mathrm{Kx}_{2}^{\prime}+\mathrm{Ky}_{2}^{\prime}\right) \mathrm{a}_{2}-\cdots-\left(\mathrm{Kx}_{\mathrm{n}}^{\prime}+\mathrm{Ky}_{\mathrm{n}}^{\prime}\right) \mathrm{a}_{\mathrm{n}}}{\left(\mathrm{Kx}_{1}^{\prime \prime}-\mathrm{Kx}_{1}^{\prime}+\mathrm{Ky}_{1}^{\prime \prime}-\mathrm{Ky}_{1}^{\prime}\right) \mathrm{a}_{1}+\left(\mathrm{Kx}_{2}^{\prime \prime}-\mathrm{Kx}_{2}^{\prime}+\mathrm{Ky}_{2}^{\prime \prime}-\mathrm{Ky}_{2}^{\prime}\right) \mathrm{a}_{2}+\cdots+\left(\mathrm{Kx}_{\mathrm{n}}^{\prime}-\mathrm{Kx}_{\mathrm{n}}^{\prime}+\mathrm{Ky}_{\mathrm{n}}^{\prime \prime}-\mathrm{Ky}_{\mathrm{n}}^{\prime}\right) \mathrm{a}_{\mathrm{n}}}(9)$

Then defined are formulas for the calculation of the unknown correctable coefficients for computing systematic incentive payments corresponding to each grade:

$$
\begin{aligned}
& \mathrm{K}_{\mathrm{x}_{\mathrm{i}}} \mathrm{K}_{\mathrm{x}_{\mathrm{i}}}+\frac{\mathrm{A}-\sum_{\mathrm{k}=1}^{\mathrm{n}}\left(\mathrm{Kx}_{\mathrm{k}}^{\prime}+\mathrm{Ky}_{\mathrm{k}}^{\prime}\right) \mathrm{a}_{\mathrm{k}}}{\sum_{\mathrm{k}=1}^{\mathrm{n}}\left(\mathrm{Kx}_{\mathrm{k}}^{\prime}-\mathrm{Kx}_{\mathrm{k}}^{\prime}+\mathrm{Ky}_{\mathrm{k}}^{\prime}-\mathrm{Ky}_{\mathrm{k}}^{\prime}\right) a_{\mathrm{k}}} \times\left(\mathrm{Kx}_{\mathrm{i}}^{\prime \prime}-\mathrm{Kx}_{\mathrm{i}}^{\prime}\right)(10) \\
& \mathrm{K}_{\mathrm{y}_{\mathrm{i}}}=\mathrm{K}_{\mathrm{y}_{\mathrm{i}}}+\frac{\mathrm{A}-\sum_{\mathrm{k}=1}^{\mathrm{n}}\left(\mathrm{Kx}_{\mathrm{k}}^{\prime}+\mathrm{Ky}_{\mathrm{k}}^{\prime}\right) \mathrm{a}_{\mathrm{k}}}{\sum_{\mathrm{k}=1}^{\mathrm{n}}\left(\mathrm{Kx}_{\mathrm{k}}^{\prime \prime}-\mathrm{Kx}_{\mathrm{k}}^{\prime}+\mathrm{Ky}_{\mathrm{k}}^{\prime}-\mathrm{Ky}_{\mathrm{k}}^{\prime}\right) \mathrm{a}_{\mathrm{k}}} \times\left(\mathrm{Ky}_{\mathrm{i}}^{\prime}-\mathrm{Ky}_{\mathrm{i}}^{\prime}\right)(11)
\end{aligned}
$$

where: $\mathrm{K}_{\mathrm{x}_{\mathrm{i}}}, \mathrm{K}_{\mathrm{y}_{\mathrm{i}}}$ - correctable coefficients for computing systematic incentive payments corresponding to each grade of remuneration;

$\mathrm{n}$ - the number of grades;

$\mathrm{k}$ - the index of summation by the numbers of grades.

According to formulas 10 and 11, the optimal set of coefficients by type of incentive payments is calculated. Given these coefficients that are calculated by the proposed method based on linear programming, the expenditure budget for employees compensation in the shoe company studied is produced (Table 3).

Table 3. The recommended techniques for budgeting expenses for employee remuneration using linear programming (on

\begin{tabular}{|c|c|c|c|c|c|c|c|c|c|c|c|}
\hline \multirow{3}{*}{ 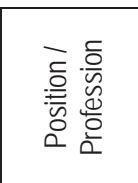 } & \multirow{3}{*}{$\begin{array}{l}\frac{0}{\pi} \\
\frac{\pi}{0}\end{array}$} & \multirow{3}{*}{ 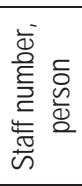 } & \multirow{3}{*}{$\begin{array}{c}\text { Expenses } \\
\text { for } \\
\text { employee } \\
\text { pay } \\
\text { rub. }\end{array}$} & \multicolumn{4}{|c|}{\begin{tabular}{c|} 
Coefficients of computing \\
systematic incentive payments
\end{tabular}} & \multicolumn{2}{|c|}{ Expenses for incentives, rub. } & \multicolumn{2}{|c|}{$\begin{array}{l}\text { Expenses for employee } \\
\text { remuneration, rub }\end{array}$} \\
\hline & & & & \multicolumn{2}{|c|}{ uncorrectable } & \multicolumn{2}{|c|}{ correctable } & \multirow{2}{*}{$\begin{array}{c}\text { Based on } \\
\text { uncorrectable } \\
\text { coefficients }\end{array}$} & \multirow{2}{*}{$\begin{array}{l}\text { Based on } \\
\text { correctable } \\
\text { coefficients }\end{array}$} & \multirow{2}{*}{$\begin{array}{c}\text { Based on } \\
\text { uncorrectable } \\
\text { coefficients }\end{array}$} & \multirow{2}{*}{$\begin{array}{c}\text { Based on } \\
\text { correctable } \\
\text { coefficients }\end{array}$} \\
\hline & & & & 矢 & 흫 充 을 & 些 & 交 & & & & \\
\hline 1 & 2 & 3 & 4 & 5 & 6 & 7 & 8 & $9=(4 \times 5)+(4 \times 6)$ & $10=(4 \times 7)+(4 \times 8)$ & $11=4+9$ & $12=4+10$ \\
\hline $\begin{array}{c}\text { Business } \\
\text { unit } \\
\text { supervisor }\end{array}$ & 9 & 1 & 12000 & 1,0 & 0,3 & 0,83 & 0,16 & 15600 & 11902 & 27600 & 23902 \\
\hline $\begin{array}{c}\text { Shop } \\
\text { foreman }\end{array}$ & 8 & 4 & 40000 & 1,0 & 0,3 & 0,83 & 0,16 & 52000 & 39672 & 92000 & 79672 \\
\hline \multicolumn{3}{|c|}{\begin{tabular}{|l|} 
Total for managerial staff \\
\end{tabular}} & 52000 & $x$ & $\mathrm{x}$ & $\mathrm{x}$ & $x$ & 67600 & 51574 & 119600 & 103574 \\
\hline \multicolumn{12}{|c|}{ Operating personnel } \\
\hline \multicolumn{12}{|c|}{ Operational area№1 (cutting and machining details of shoe bottom) } \\
\hline Detail cutter & 4 & 3 & 17941 & 1,0 & 0,3 & 0,83 & 0,16 & 25697 & 19605 & 43638 & 37546 \\
\hline Machinist & 2 & 3 & 13801 & 1,0 & 0,3 & 0,83 & 0,16 & 19767 & 15081 & 33568 & 28882 \\
\hline $\begin{array}{l}\text { Assembly } \\
\text { worker }\end{array}$ & 4 & 5 & 29901 & 1,0 & 0,3 & 0,83 & 0,16 & 42829 & 32675 & 72730 & 62576 \\
\hline \multicolumn{12}{|c|}{ etc. } \\
\hline \multicolumn{3}{|c|}{$\begin{array}{l}\text { Total for operating } \\
\text { personnel }\end{array}$} & 1387873 & $x$ & $\mathrm{x}$ & $x$ & $\mathrm{x}$ & 1987901 & 1506561 & 3375774 & 2894434 \\
\hline \multicolumn{3}{|c|}{$\begin{array}{c}\text { Total for support } \\
\text { personnel }\end{array}$} & 39881 & $x$ & $\mathrm{x}$ & $x$ & $\mathrm{x}$ & 56594 & 43177 & 96475 & 83058 \\
\hline \multicolumn{3}{|c|}{ Total for business unit } & 1479755 & $\mathrm{x}$ & $\mathrm{x}$ & $\mathrm{x}$ & $\mathrm{x}$ & 2112095 & 1601312 & 3591850 & 3081067 \\
\hline
\end{tabular}
the example of JSC "Shoe company "Spartak")

1 - calculated by formula 10 ;

2 -calculated by formula 11 . 


\section{Conclusions}

These results demonstrate that the use of linear programming in budgetary management of expenses for compensation contribute to a more efficient funds allocation for the payment of workers. Since by linear programming it is possible to determine the optimal coefficients for computing staff incentive payments which take into account the most appropriate level of change in the correlation between an increase in the average amount of labor remuneration for one percent increase in worker productivity. In addition, the proposed approach to budgeting funds for remuneration assumes joint responsibility of the company's employees for results, as correctable coefficients are calculated on the basis of the labor remuneration of all staff, not just the production staff.

Thus, the use of linear programming in the budgeting system helps organizations to optimize the expenses for compensation and to encourage workers to increase productivity.

\section{References}

Boatsman, J.R., Moeckel, C., Pei, B.K.W. The Effects of Decision Consequences on Auditors' Reliance on Decision Aids in Audit Planning //_Organizational Behavior and Human Decision Processes, 71 (2), 1997. pp. 211-247.

Choe, J.-M. The Organisational Learning Effects of Management Accounting Information Under Advanced Manufacturing Technology /I European Journal of Information Systems, 11 (2), 2002. pp. 142-158.

Díaz-Madroñero, M., Mula, J., Peidro, D. A Review of Discrete-Time Optimization Models for Tactical Production Planning // International Journal of Production Research 52 (17), 2014. pp. 5171-5205.

Glover, S.M., Jiambalvo, J., Kennedy, J. Analytical Procedures and Audit-Planning Decisions // Auditing, 19 (2), 2000. pp. 26-45.

Jaradat, M.M.F., Jawabreh, O.A.A., Saleh, M.M.A., Abu-Eker, E.F.M. The Extent of Applying the Methods of Management Accounting in Planning, Controlling and Pricing in Aqaba hotels // European Journal of Economics, Finance and Administrative Sciences. Issue 36, August, 2011. pp. 123-132.

Ke, H., Ma, W., Ni, Y. Optimization Models and a GA-based Algorithm for Stochastic Time-cost Trade-off Problem // (2009) Applied Mathematics and Computation, 215 (1), 2009. pp. 308-313.

Khalaf, W.S., June, L.W., Abu Bakar, M.R.B., Soon, L.L. A linear programming approach to maximize savings by stretching noncritical activities // Australian Journal of Basic and Applied Sciences. Volume 4, Issue 11, November 2010. pp. 5649-5657.

Kwak, W., Shi, Y., Jung, K. Human Resource Allocation in a CPA firm: A Fuzzy Set Approach // Review of Quantitative Finance and Accounting. Volume 20, Issue 3, 2003. pp. 277-290.

Liu, Y.-H., Shi, Y. A Fuzzy Programming Approach for Solving a Multiple Criteria and Multiple Constraint Level Linear Programming Problem. Fuzzy Sets and Systems, 65 (1), 1994. pp. 117-124.

Steger-Jensen, K., Hvolby, H.-H., Nielsen, P., Nielsen, I. Production Planning and Control // Advanced Planning and Scheduling Technology. Volume 22, Issue 8, December 2011. pp. 800-808.

Szklo, A.S., Maia, L.O.A., Qassim, R.Y. A kaizen budgeting model // International Journal of Technology Management. Volume 13, Issue 1, 1997. pp. 78-83. 